\title{
SYMPOSIUM ON THEORIZING TWAIL ACTIVISM
}

\section{ENACTING TWAILIAN PRAXIS IN NONACADEMIC HABITATS: TOWARD A CONCEPTUAL FRAMEWORK}

\author{
Obiora Chinedu Okafor*
}

The roles that Third World Approaches to International Law (TWAIL) scholars could play in political and/or socio-economic struggles beyond the academy, and the relationships of these scholars to politicians, diplomats, activists, civil servants, peasant movements, civil society, and other nonacademic actors are issues as important to TWAIL as they are understudied and underenacted. ${ }^{1}$ The three essays in this TWAIL Symposium take up this theme of praxis.

This essay contributes to discussions of the ways and means of enhancing the TWAIL scholars' effectiveness in nonacademic settings, especially in "pro-Third World subaltern" struggles within, or in concert with, international institutions (such as the United Nations) and on-the-ground activist groups (such as social movements and NGOs). It offers an initial outline for TWAILian praxis in such settings.

The concepts of TWAIL and praxis require some explanation at the outset. While TWAIL is an umbrella signifier for a broad and internally diverse range of scholars,

TWAIL scholars (or "TWAILers") are solidly united by a shared ethical commitment to the intellectual and practical struggle to expose, reform, or even retrench those features of the international legal system that help create or maintain the generally unequal, unfair, or unjust global order . . . a commitment to centre the rest rather than merely the west, thereby taking the lives and experiences of those who have self-identified as Third World much more seriously than has generally been the case. ${ }^{2}$

* York Research Chair in International and Transnational Legal Studies at the Osgoode Hall Law School, York. University, Toronto, Canada; and Member, United Nations Human Rights Council Advisory Committee, Geneva, Switzerland. This contribution is based on a small part of the author's keynote address to the TWAIL Conference "On Praxis and the Intellectual" held at the American University in Cairo, February 21-24, 2015.

Originally published online 02 August 2016.

${ }^{1}$ See Conference Program, Third World Approaches to International Law: On Praxis and the Intellectual 1.

2 Obiora Chinedu Okafor, Newness, Imperialism, and International Legal Reform in Our Time: A TWAIL Perspective, 43 OsgoOde HALL L.J. $171,176-177(2005)$. 
Most contemporary usages of the term "praxis," certainly those in the Marxian tradition, ${ }^{3}$ have embedded some notion of the inherent unity of thought and action, and of the "inseparability of theory and practice" or at least of the critical desirability of such a unity and inseparability. ${ }^{5}$ For Vincent Mosco,

Praxis guides a theory of knowledge to view knowing as the ongoing product of theory and practice. It rejects as partial those epistemologies which conclude that truth [or to put it more carefully, knowledge] can only result from contemplation. Rather it grows out of the mutual constitution of conception and execution. ${ }^{6}$

This essay employs the concept of praxis in Mosco's sense of the mutual constitution of conception and execution, and of the unity (or unification) of theory imbued-action and action imbued-theory. Along the same lines, some have explained praxis as denoting forms of "thoughtful doing."”

On this conception, there is a sense in which TWAIL itself is already praxis. For one, TWAIL is avowedly a scholarly and political movement with broadly unifying "political and transformative commitments." And, as Pooja Parmar has noted, the lives and struggles of third-world peoples are central to TWAIL. . Second, many of the things that many TWAILers do in an academic setting can add up to a form of praxis: For example, who we choose to cite in our writings; ${ }^{10}$ who and what we choose to teach in our courses; who we chose to read most in the context of scarcity of time; which graduate students we choose to take on; and which directions we choose to encourage these students to take. All of these are crucial forms and instantiations of praxis.

Forms of praxis within the academy cannot be neatly or tightly separated and sealed off from any of the other forms of praxis that we can and do enact. However, this essay concentrates on TWAIL praxis within, or in relation to, institutional, popular and other habitats. Although under-studied, the crucial questions raised by this theme have been hinted at previously in TWAIL circles. Indeed, over time, they have agitated the minds of many. The 1997 Vision Statement that formally inaugurated the contemporary TWAIL era appears to contemplate this kind of "praxis beyond the academy" when it commits TWAILers to the task of "disseminating" their critical insights. ${ }^{11}$ B.S. Chimni has persistently called on us to "project an alternative vision of international law" (presumably, including to the world beyond the academe). ${ }^{12}$ In the TWAIL literature, other long-standing recognition of the importance of paying a certain attention to praxis includes Upendra Baxi's deep concern with struggles and social action, ${ }^{13}$ Makau Mutua's push for the transformation of human rights NGOs, Balakrishnan Rajagopal's abiding focus on "resistance," and Luis Eslava and Sundhya Pahuja's joint call on us to

3 A. Claire Cutler, Toward a Radical Political Economy Critique of Transnational Economic Law, in INTERNATIONAL LAW ON THE LEFT: REExamining Marxist Legacies 199, 216, 219 (Susan Marks ed., 2008); Herbert MARCuSE, Studies In Critical Philosophy 5 (Joris de Bres transl., 1972).

${ }^{4}$ Emmanuelle Jouannet, Koskenniemi: A Critical Introduction, in The Politics of InTERnational Law 1, 3 (Martti Koskenniemi ed., 2011).

${ }^{5}$ Rebekah L. Fox \& Joshua J. Frye, Tensions of Praxis: A New Taxonomy for Social Movements, 4 ENVTL. ComM. 422 (2010); Stephen Kemmis, Research for Praxis: Knowing Doing, 18 Pedagogy, Culture \& SOC’Y 9 (2010); Gail Furman, Social Justice Leadership as Praxis: Developing Capacities Through Preparation Programs, 48 EduC. AdmIN. Q. 191 (2012).

6 See Vincent Mosco, The Political Economy of Communication 35 (2d ed., 2009) (emphasis added).

${ }^{7}$ Martha J. Dede, The Praxis Journal: Integrating Theory and Practice, 8 J. PuB. AfF. EDUC. 287 (2002).

8 See Call for Papers, Third World Approaches to International Law Conference, UNIVERSITY OF WINDSOR and Conference Program, Third World Approaches to International Law: On Praxis and the Intellectual; See also, Okafor, supra note 2; Karin Mickelson, Taking Stock of TWAIL History, 10 InT'L Community L. Rev. 355, 357 (2008); Luis Eslava \& Sundhya Pahuja, Between Resistance and Reform: TWAIL and the Universality of International Law, 3 TRADE, L. \& DEV. 103, 109 (2011).

9 See Pooja Parmar, TWAIL: An Epistomological Inquiry, 10 InT'L COMMUnity L. REv. 363.

${ }^{10}$ Compare, e.g., Robert S. Chang, Richard Delgado and the Politics of Citation, 11 Berkeley J. Afr.-AM. L. \& POL'y 28 (2009).

${ }^{11}$ For a restatement and analysis of this vision statement, see Mickelson, supra note 8, at 357-358.

12 B.S. Chimni, Third World Approaches to International Law: A Manifesto, 8 InT’L Community L. Rev. 3, 25 (2006) (emphasis added).

13 See Upendra Baxi, The Future of Human Rights 41 (2006). 
"get down and dirty" and "delve into the everyday life of international law."14 In most of these cases, the authors have actively engaged with activists, international institutions, or both.

More recently, there are calls for TWAILers to engage international institutions and on-the-ground groups more intensively in order to "disseminate" and "project" their alternative visions of international law and global society more effectively. For instance, following the broad thrust and implications of the work done by Chimni et al., Opeoluwa Badaru has called on TWAILers to deal more squarely and directly with how TWAILers' visions can be further incorporated into the work of social movements on the ground. ${ }^{15}$

The main question raised is: What would it mean for us to enact TWAIL praxis in relation to, or from within, the specific habitats in which international and domestic civil servants, politicians, activists, advocates, revolutionaries, civil servants, soldiers, artists, writers, union representatives, civil society leaders, and peasant movements are more readily found and accessed? From my own reflections on TWAIL and other critical internationalist literature, and my experience of close engagement with and within at least one international institution, it seems that effective TWAIL praxis in these kinds of nonacademic habitats or environments would need to be guided by the following conceptual/normative framework (constituted by commitments, insights, resources, sensibilities, and concerns):

\section{A Commitment to a Broadly TWAILian Style and Substance in our Work}

Since the TWAIL literature already brims with such commitment, little needs to be said about it here. ${ }^{16}$

\section{A Significant Measure of Theoretical/Conceptual Clarity as to the Goals of TWAIL}

Despite clarity that we should stand in opposition to all the international norms and institutions that facilitate and maintain the domination, impoverishment and immiseration of third-world peoples, TWAILers may disagree about the goals to be pursued in particular concrete circumstances. For example, given important criticism of the International Criminal Court (ICC) for its current geo-stationary orbit over only the African continent, ${ }^{17}$ should TWAIL work toward the abolition of the ICC, or simply its reform? 18

\section{The Recognition That There is Room in Nonacademic Praxis for Both the "Situated Participant" and the "External Ob- server", Without There Necessarily Being a Radical Separation Between These Two Postures}

In Martti Koskienniemi's theoretical reflections on his own close engagements with and within the UN Security Council, ${ }^{19}$ he distinguishes between the "situated participant" (who tends to have an "internal or engaged

14 See Makau Mutua, Human Rights: A Political and Cultural Critique (2008); Balakrishnan Rajagopal, International LaW From Below: Development, SOCial MOVEMENTS AND Third World ResistanCe (2003); Eslava \& Pahuja, supra note 8 , at 123.

15 Opeoluwa Badaru, Examining the Utility of Third World Approaches to International Law for International Human Rights Law, 10 INT'L Community L. Rev. 379, 385-386 (2008).

16 Okafor, supra note 2; James T. Gathii, TWAIL: A Brief History of Its Origins, Its Decentralized Network, and a Tentative Bibliography, 3 Trade, L. \& DEv. 26, 27 (2011); Makau Mutua, What is TWAIL? 94 ASIL ProceEdings 31 (2000); Parmar, supra note 9.

17 See Obiora Chinedu Okafor \& Uchechukwu Ngwaba, The International Criminal Court as a 'Transitional Justice' Mechanism in Africa: Some Critical Reflections, 9 InT'L J. Transitional Just. 90, 99-101 (2015); and Obiora Chinedu Okafor \& Uchechukwu Ngwaba, Between Tunnel Vision and a Sliding Scale: Power, Normativity and Justice in the Praxis of the International Criminal Court (forthcoming).

18 This issue was addressed in the first of the TWAIL symposia in AJIL Unbound. See James T. Gathii \& Henry J. Richardson, III, Introduction to Symposium on TWAL Perspectives on ICL, IHL, and Intervention, 109 AJIL UnBound 252 (2016); Asad G. Kiyani, Third World Approaches to International Criminal Law, 109 AJIL UnBOUND 255 (2016), Parvathi Menon, Self-Referring to the International Criminal Court: A Continuation of War by Other Means.

19 See Martti Koskenniemi, The Place of Law in Collective Security, 17 Mich. J. INT’L L. 455, 465 (1995-1996). 
perspective" on such institutions) and the "external observer" (who tends not to possess that perspective routinely). ${ }^{20}$ However, it is important to note that these positions can be assumed by one and the same person. For instance, a TWAILer may one day sit on a UN human rights body or the board of a human rights group, and return the next day to her "regular" job as a professor. While one job may be different from the other, they do not necessarily exist in impermeable silos. What is more, to be as effective as $\mathrm{s} /$ he can be in enacting a form of TWAIL praxis in a nonacademic setting, the situated TWAIL participant must plug into the TWAIL electricity grid that is kept alive largely by TWAILers who have mostly remained external observers.

\section{The Recognition of the Growing Need to Reach Beyond the Typical Sites of Engagement}

I must confess that my own nonacademic praxis (hopefully transmitted on a TWAIL frequency) has focused more on the typical sites of engagement. Here, I am beholden to the work of Luis Eslava and Sundya Pahuja who have advocated that TWAIL praxis (what might be referred to as either execution-in-contemplation or contemplation-in-execution) pay attention to the:

many other sites and objects in which international law operates today. In particular, it is crucial that we start examining the way[s] in which international law unfolds on the mundane and quotidian plane through sites and objects which appear unrelated to the international. Administrative procedures, subject formations, spaces and artifacts that are usually identified as expressions of other normative orders, social spheres or simply innocuous technical or commercial things, are the very material sites in which international disciplines are at work. ${ }^{21}$

5. The Better and More Exact Appreciation of the Opportunities and Limitations of (International) Law and Lanyers While Engaged in Praxis Within Nonacademic Habitats

As well appreciated as this insight already is, ${ }^{22}$ especially among schools of critical scholarship such as TWAIL, Martti Koskenniemi's reflections on it remind us that the specificities of international institutions and of on-the-ground groups require constant reappreciation. Koskenniemi's experience as legal adviser to the Finnish delegation to the UN Security Council made clear to him that international law and lawyers generally play a more marginal role in the dramas that are enacted in the atmosphere of high politics. ${ }^{23}$ As he recalled, "where the political framework was stable, the lawyer was the ... [handmaid] of the politician, helping out if new language for negotiation and consensus was needed" but "things looked different when a non-routine issue emerged" and international law and lawyers assumed a more central role. ${ }^{24}$

\section{A Commitment to a Broadly Integrated and Interdisciplinary Style/Substance}

This point flows logically from an appreciation of the last and is already well recognized by TWAILers. If politics (or at least nonlegal maneuvers and the like) more routinely plays the central role in the nonacademic habitats in which we seek to enact TWAIL praxis, then our praxis must adjust to the context and integrate (as much as possible and desirable) both the legal and the political. What is more, as is well recognized, a law/politics binary is not even possible. For, as Koskenniemi has long observed in the context of his work at the UN

${ }^{20} \underline{I d}$. at $465-471$.

21 See Eslava \& Pahuja, supra note 8, at 109.

22 For example, see Gerald N. Rosenberg, The Hollow Hope: Can Courts Bring About Social Change? (2d ed., 2008).

23 See Koskenniemi, supra note 18, at 473.

24 See id. at 473-474. 
Security Council, "political choices ... [tended to be] posed the moment the legal debate started" and there were no "separate pigeon-holes" for "law" and "politics," as law and politics seemed coherent and separate, yet related to one single entity." 25

7. The Recognition That the Longer Term Goal of TWAIL Praxis is Transformative and not Merely to Effect Marginal Change

As this is a fairly obvious point about which TWAILers tend to agree, there is little more to say here.

While these seven guidelines are merely an initial outline of a framework for TWAIL praxis in nonacademic settings, the outline is designed to spur further enquiry and debate.

The promise of TWAIL praxis within, or in relation to, international institutions and on-the-ground groups must be modulated by its potential perils (the discussion of which is well beyond the scope of this short essay). However, a scholarly and political movement like TWAIL cannot afford to continue to underenact TWAIL praxis in the nonacademic habitats that are home to socio-political actors including international institutions and on-the-ground activist groups. We will do very well to remember that as the richly fecund mind of the great poet, Christopher Okigbo, once imagined and he then voiced:

And he said to the ram: Disarm

And I said:

Except by rooting

Who could pluck yam tubers from their base?26

TWAIL cannot simply command the ram (the global power matrixes) to "disarm" and have it comply. Although it may not be entirely correct to state, as Marx did in 1845, that, "the philosophers have only interpreted the world, in various ways; the point is to change it," 27 the point remains that some degree of effective and targeted praxis beyond our relatively narrow comfort zone within the academy seems nevertheless to be required.

25 See id. at 475.

26 See Christopher Okigbo, Collected Poems 25 (1986).

27 Karl Marx, Theses on FeuerbaCH (1845). 